\title{
O synergii planu w urbanistyce
}

\section{Zbigniew Karol Zuziak}

\author{
Katedra Planowania Przestrzennego i Ochrony Środowiska, \\ Wydziat Architektury, Politechnika Krakowska, e-mail: zzuziak@nsnet.pl
}

Streszczenie: Autor artykułu traktuje synergię jako kryterium oceny efektywności strategii urbanistycznych, a także formuły oraz ustaleń planu urbanistycznego. Przyjmując perspektywę, którą określa mianem „urbanistyki strategicznej”, formułuje ideę urbanistycznego modelu decyzyjnego nazywając go hasłem SAS (akronim od: Strategie, Aktorzy, Struktury). Oznacza to, że w urbanistyce, potencjalne efekty synergii powinny być interpretowane w kontekście zasad przyjętych w dokumentach miejskich polityk i strategii rozwoju, przy założeniu, że ustalenia te podejmowane są przez ,aktorów gry o przestrzeń urbanistyczną” ze świadomością strukturalnych mechanizmów samoregulacji i strukturalnych konsekwencji przyjętych strategii. Mowa tu o miejskich politykach publicznych i strategiach sektora prywatnego - a także zintegrowanych strategiach publiczno-prywatnych stosowanych w miastach europejskich, które wyróżniają się wysokim poziomem warsztatu urbanistycznego. W Polsce, stosowanie tak innowacyjnych podejść wymagałoby głębokich reform systemu sterowania rozwojem urbanistycznym. Zakłada się, że w ich wyniku pojawią się nowe narzędzia umożliwiające lepsze zintegrowanie planowania przestrzennego, strategicznego, urbanistyki operacyjnej oraz projektowania urbanistycznego. Autor identyfikuje atrybuty planu urbanistycznego, które mogą sprzyjać powstawaniu synergii polegającej na wzajemnie korzystnych oddziaływań między projektami miejskimi. $\mathrm{W}$ analizie tego rodzaju powiązań, układem odniesienia staje się ,konstrukcja urbanistycz$n a$ ". Wg. autora pojęcie to może odegrać istotną rolę w rozwijaniu metod i technik zapisu ustaleń planistycznych $\mathrm{w}$ formule planowania zintegrowanego. Tworzenie logicznych powiązań między projektami urbanistycznymi a konstrukcją urbanistyczną, zdefiniowaną w planie rozwoju miasta, jest warunkiem koniecznym uzyskania synergii pojmowanej jako korzyści dodatkowe z tytułu prawidłowych relacji funkcjonalnych między projektami. Badania nad przykładami dobrej praktyki w zakresie urbanistyki operacyjnej i strategicznej wskazują, że efekty wzajemnie korzystnych oddziaływań między projektami urbanistycznymi powstają w przypadkach, w których: 1) istnieje zinstytucjonalizowana i dobrze zorganizowana kooperacja między aktorami strategii urbanistycznych; 2) w ustaleniach planistycznych znajdują się czytelne zapisy dotyczące strukturalnych aspektów planowanego układu urbanistycznego. Autor skupia się na potencjalnych relacjach synergicznych między projektami przebudowy śródmieść. Zakłada, że badanie tego rodzaju relacji to istotny element analitycznej podbudowy planów rewitalizacji śródmieść. Efekt synergii byłby znaczącym kryterium oceny ustaleń takich planów.

Słowa kluczowe: synergia, planowanie urbanistyczne, urbanistyka, projekty miejskie, konstrukcja urbanistyczna.

\section{Wstęp}

Przyjmuje się powszechnie, że synergia to: „współdziałanie różnych czynników, którego efekt jest większy niż suma poszczególnych oddzielnych działań” (Wikipedia). Ujmując 
rzecz inaczej, myślenie w kategoriach synergii wywodzi się z ogólnego, iście filozoficznego przekonania, że calość, to więcej niż suma części. Jednak na gruncie urbanistyki istotne są również inne aspekty podkreślane w definicjach synergii. Mowa tu o takich atrybutach strategii urbanistycznych, a także celach polityki przestrzennej, jak: koordynacja, integracja działań i struktur, harmonizujące, i uzupełniające się działania, prowadzące do znacznego wzrostu efektywności, konfigurowanie projektów komplementarnych, itp. Szczególnego znaczenia nabierają tu pojęcia integracji i koncentracji, a ściślej: synergiczna interpretacja zasady integracji i prawa koncentracji, które to zasady należą przecież do kanonu reguł uznawanych powszechnie w teorii urbanistyki [1].

Celem tej publikacji jest wyartykułowanie planistycznych aspektów zmian w przestrzeni urbanistycznej dających się logicznie powiązać z synergicznymi właściwościami (synergicznym potencjałem) „szkieletu” konstrukcyjnego nazwanego tu „konstrukcja urbanistyczna". U podstaw takiego zamierzenia tkwi przekonanie, że w pojęciu synergii tkwi spory ładunek inspiracji a taki kierunek myślenia może być przydatny zwłaszcza dla tych, którzy poszukują nowych uogólnień wyjaśniających istotę efektywności strategii urbanistycznych. W tym kontekście można nawet mówić o „synergicznych strategiach rozwoju terytorialnego." Zakłada się, że strategie takie powinny odgrywać kluczową rolę $\mathrm{w}$ racjonalnym sterowaniu zmianami w zagospodarowaniu przestrzennym miast. Oznacza to również konieczność powiązania polityk przestrzennych - i odpowiadających im strategii - z nowymi interpretacjami miejskich mechanizmów strukturotwórczych $[1,2,3]$, a zwłaszcza z teoriami, które wyjaśniają logikę formy urbanistycznej w kontekście wzorców mobilności, rozwoju systemów transportowych $[2,4,5,6]$ oraz doktrynalnych podstaw polityki przestrzennej. Mowa tu przede wszystkim o ujęciach sytuujących się na styku trzech nurtów teorii urbanistycznej [7], a mianowicie:

- interpretacji bliskich duchowi neoliberalizmu, które akcentują rolę samoregulacji / samoorganizacji w procesach przekształcania struktur miejskich;

- doktryn uznających konieczność publicznej interwencji - nawet aktywnej polityki miejskiej - w imię ochrony dóbr wspólnych, idei ładu przestrzennego, potrzeby ograniczania negatywnych efektów zewnętrznych rynku, zapewnienia i bardziej racjonalnych form gospodarowania przestrzenią miejską (ograniczanie konfliktów generowanych przez zmiany w zagospodarowaniu przestrzennym);

- teorii, które - na zasadzie „złotego środka” - próbują, w różnych proporcjach, kojarzyć wyżej wymienione podejścia.

Przedmiotem rozważań autora są planistyczne uwarunkowania synergii, które 1) dotyczą rozwoju śródmieść o znaczeniu metropolitalnym i 2) rozpatrywane są z perspektywy planowania przestrzennego, urbanistyki operacyjnej oraz projektowania urbanistycznego. Akcent położono na okoliczności w jakich powstają synergiczne relacje między projektami miejskimi, które - traktowane łącznie - tworzą funkcjonalny i przestrzenny układ spójny z celami i kierunkami strategii rozwoju. Okoliczności te powinny wiązać się logicznie $\mathrm{z}$ ustaleniami odpowiednich planów zagospodarowania przestrzennego i $\mathrm{W}$ takim sensie można mówić o synergii planu urbanistycznego.

Kompozycję tekstu tworzą trzy części - trzy warstwy tematyczne dotyczące obecności pojęcia synergii w teorii urbanistycznej oraz w metodach i technikach praktyki planowania miast. W części pierwszej, sformułowano założenia teoretyczne na temat „,konstrukcyjnych" i planistycznych aspektów synergii, w drugiej starano się wykazać ich związek z doświadczeniami planistycznymi, które zilustrowano słynnymi już przykładami planowania rozwoju metropolitalnej Kopenhagi oraz regionu Kopenhaga-Malmö. W części trzeciej zarysowano metodologiczną koncepcję analiz urbanistycznych mających na celu uchwycenie potencjalnych relacji synergicznych miedzy projektami urbanistycznymi o kluczowym znaczeniu dla budowania nowej konstrukcji urbanistycznej śródmieść Krakowa i Poznania. 


\section{Pojęcie synergii urbanistycznej}

W ostatniej dekadzie, hasło „synergia” pojawia się coraz częściej w literaturze urbanistycznej. Trzymając się przytoczonej na wstępie „klasycznej” już definicji synergii, można byłoby wprowadzić pojęcie ,synergii urbanistycznej” i zdefiniować ją jako: wzajemne oddziaływania podmiotów i przedmiotów urbanistycznej rzeczywistości (np.: aktorów ,gry o przestrzeń miejską", ich strategii i polityk miejskich, strukturalnych elementów przestrzeni miejskiej, projektów urbanistycznych, itp.), których lączny efekt jest większy niż suma oddziaływań poszczególnych elementów. W definicji tej akcent położony jest na synergiczne efekty zmian w zagospodarowaniu przestrzennym spójne ze strategiami i politykami urbanistycznymi, ale z uwzględnieniem ,synergicznej samoregulacji” (współdziałania/wzajemne oddziaływania mające charakter samoorganizacji).

Pojęcie synergii znajdujemy w różnych obszarach tematycznych publikacji naukowych poświęconych urbanistyce, planowaniu przestrzennym i zarządzaniu rozwojem miejskim. Są to teksty na temat: a) ekonomicznych i organizacyjnych zagadnień rozwoju miast i zarządzaniu projektami rozwoju (zwłaszcza efektowi komplementarności projektów prowadzonych w ramach programów rozwoju regionalnego), b) problemów modelowania rozwoju urbanistycznego $[1,2,10,19,20]$, c) morfologii urbanistycznej $[3,10,11,19,20,21$, 22], d) potencjalnego pola synergii między planowaniem a ochroną dziedzictwa kulturowego $[3,7,23]$, e) synergicznym aspektom relacji: transport a zagospodarowanie przestrzenne $[1,2,4,5,13,16]$, a także - co jest najbliższe tematyce tego artykułu - e) strukturalnym przekształceniom miejskich obszarów funkcjonalnych badanych w kontekście zadań, jakie stąd wynikają dla planowania urbanistycznego $[3,7,11,16,17]$.

Już tak pobieżny przegląd literatury tematu wskazuje, że owa wielowątkowość bynajmniej nie ułatwia zadania tym, którzy chcieliby sformułować podstawy teorii na temat roli, jaką zjawiska synergii odgrywają w sterowaniu rozwojem urbanistycznego a także ich związek z tymi zmianami w zagospodarowaniu przestrzennym, które określa się mianem procesów strukturotwórczych. Tutaj interesuje nas, przede wszystkim, pytanie: jak te, dość szeroko zakreślone, obszary teorii urbanistycznej, w której pojawia się pojęcie synergii, można odnieść do praktyki rozwiązywania problemów urbanistycznych.

Publikacje, które kojarzą ideę synergii z problemem integracji przestrzeni urbanistycznej $[8,9,10,11,12]$ oraz badaniami nad transformacją struktur miejskich / metropolitalnych $[13,14,15,16,17]$ - zwłaszcza w kierunku modeli sieciowych $[18,19,20]$ i ujęć morfologicznych $[21,22]$, - a także rozważań nad problemem racjonalności w urbanistyce $[3,11$,$] , prowadzą do pytań na temat:$

- narzędzi poznawczych pozwalających uchwycić zjawiska synergii w miejskich procesach strukturotwórczych,

- uwarunkowań synergicznego modelu sterowania rozwojem urbanistycznym, oraz

- atrybutów planu urbanistycznego, dzięki którym rośnie prawdopodobieństwo uzyskania efektów synergicznych [3,23].

Tego rodzaju pytania wymagają abyśmy wyszli poza krąg rozważań na temat klasycznego instrumentarium polityki przestrzennej i poszerzyli nasz obszar dyskusji odwołując się do „podstawowych praw urbanistyki”: do kwestii, które dotyczą podstawowych mechanizmów rozwoju urbanistycznego. Innymi słowy, mowa tu o synergii, jako perspektywie badawczej pozwalającej lepiej zrozumieć logikę struktur miejskich. Wspólnym mianownikiem obu tych sposobów interpretowania zmian w strukturach przestrzennych jest pojęcie „oddziaływań urbanistycznych”: „sił”, czy też czynników, strategicznej i strukturalnej dynamiki układów miejskich. Odnosząc te czynniki do zjawiska synergii możemy mówić o synergii rozwoju urbanistycznego i odpowiadających mu struktur. Idąc tym 
tropem, należałoby przede wszystkim zapytać: Jakie oddzialywania urbanistyczne wywotują efekty synergii i na czym te skutki polegają?

Tak ogólnie zarysowany obszar problemowy prowadzi do kwestii bardziej szczegółowych, takich jak - przykładowo - pytania o logiczne związki między czynnikami i formami synergii a:

- ideą porządku w przestrzeni urbanistycznej [3,11];

- modelowaniem struktur urbanistycznych [1,2,5,18,19,20];

- instrumentami polityk i strategii rozwoju miast, obszarów metropolitalnych i regionów miejskich / metropolitalnych [3,11,13,5].

Obserwacja urbanistycznej rzeczywistości wskazuje jednak, że szanse pojawienia się takich logicznych relacji nie są bynajmniej oczywiste. Można nawet pójść dalej i twierdzić, że w wielu miastach (w tym również w Polsce) poziom skoordynowania działań urbanistycznych pod względem kryteriów strukturalnych jest stosunkowo niewielki. Jeśli nawet w ustaleniach planów zagospodarowania przestrzennego znaleźć możemy zapisy wskazujące na konieczność zapewnienia funkcjonalnych i kompozycyjnych powiązań między projektami - i pakietami projektów usytuowanych w obszarach o kluczowym znaczeniu dla strategii rozwoju miasta - to w praktyce realizacja tego rodzaju ustaleń napotyka wiele trudności.

W prezentowanym tu ujęciu, problem synergii w urbanistyce, a ściślej: problem synergii planu urbanistycznego, można traktować jako zbiór zagadnień wpisujących się w tematykę podstawowego problemu urbanistyki i architektury: problemu integracji przestrzennej struktury miasta. Jego ranga rośnie w kontekście różnych przejawów dezintegracji charakterystycznych dla miasta neoliberalnego. W urbanistyce neoliberalnej strategie rozwoju w sposób pragmatyczny skupiają się na projektach kluczowych. Powiązania między nimi są stosunkowo słabe, co ogranicza możliwość uzyskania efektów synergicznych. W takim kontekście pojawia się pytanie: Czy działania skupiające się na kluczowych projektach urbanistycznych ale zapewniające również odpowiednie powiązaniach między tymi projektami mogą prowadzić do efektów synergicznych porównywalnych do urbanistycznej akupunktury?

Rozważania na temat „konstrukcyjnych” aspektów synergii w urbanistyce zacząć wypada od relacji: synergia - integracja. Taki punkt wyjścia wydaje się szczególnie obiecujący dla teoretycznych uogólnień nawiązujących bezpośrednio do praktyki urbanistycznoarchitektonicznej. Przykładowo, Jan Wrana w swojej monografii pt.: Rola $i$ znaczenie architektury $w$ procesie scalania struktury przestrzennej miasta na przykładzie Lublina [14 s.54] proponuje metodę integracji przestrzennej struktury Lublina, którą nazywa „metoda synergii”. W metodzie tej istotną rolę odgrywa „scalanie struktury miasta w punktach węzłowych" [14, s.65] oraz ,architektura integracyjna”. Tym samym autor ten akcentuje rolę czynnika synergii w kompozycji urbanistycznej, nawiązując w ten sposób do idei Aleksandra Böhma przedstawianej ponad 30 lat temu w rozprawie „O budowie $i$ synergii wnętrz urbanistycznych" [25]. Wypada też zauważyć, że kojarząc problematykę synergii z kompozycją sieci przestrzeni publicznych, Wrana nawiązuje też do klasycznej już teorii kompozycji urbanistycznej Kazimierza Wejcherta z 1974 r. [26]. Dodajmy też, że ostatnio, ten rodzaj „synergicznego” nurtu teorii urbanistycznej widoczny jest również w publikacjach Joan Busquets [27] i Hana Meyera [28], które w nowy sposób wiążą problematykę kompozycji urbanistycznej z czynnikiem synergii w rozwoju miejskim.

Interpretując pojęcie synergii na poziomie teorii, a nawet „filozofii urbanistyki”, można bronić tezy, że synergia stanowi o istocie miejskości. Ma też wpływ na formowanie się klastrów i wiąże się z powstawaniem takich układów osadniczych jak aglomeracje, konurbacje czy regiony miejskie. Pojęcie synergii jest również istotnym komponentem 
teorii wyjaśniających koncepcje „miasta sieci”. Reasumując, w urbanistyce i planowaniu przestrzennym wyróżnić można pięć, rodzajów synergii. Są to synergiczne właściwości/aspekty:

- rozwoju urbanistycznego (synergiczne czynniki rozwoju miast i obszarów zurbanizowanych) - polegającej przede wszystkim na synergicznych sprzężeniach między układami transportowymi a zagospodarowaniem przestrzennym;

- planu urbanistycznego;

- konstrukcji i formy urbanistycznej (geometryczne cechy fizycznego układu integrującego przestrzenne zagospodarowanie miasta / śródmieścia, dzięki czemu w przestrzeni tej pojawiają się efekty synergiczne; synergia infrastruktury, układów krystalizujących);

- koncentracji / aglomeracji (synergiczny efekt bliskości; synergia kontaktów między podmiotami życia miejskiego / aktywnościami / działaniami / rodzajami użytkowania; synergia: sieci, klastrów, układów radio-koncentrycznych, „kłączy” itp.);

- lokalizacji i rynku nieruchomości (,zasada najlepszego użytkowania”; synergia relacji: dostępność a wartość nieruchomości).

W dalszej części zajmiemy się trzema pierwszymi kategoriami synergii: synergią rozwoju urbanistycznego, synergią planu i synergicznymi właściwościami konstrukcji urbanistycznej.

\section{Synergia rozwoju, planu i konstrukcji urbanistycznej}

Ideę synergii rozwoju urbanistycznego wyrazić można w postaci zapisu:

$$
S_{u d}=\{L u f, L u d p\},
$$

gdzie: $S_{u d}$ - oznacza synergię rozwoju urbanistycznego (synergy of urban development), Luf - oznacza logikę formy urbanistycznej (logic of urban form), a Ludp - logikę procesu rozwojowego (logic of urban development proces).

Pojęcie: logika formy urbanistycznej pojmować należy jako postrzegalne (dające się zwizualizować) konstrukcyjne/strukturalne i funkcjonalne powiązania między atrybutami przestrzennego zagospodarowania miasta (konstrukcyjne powiązania między fizycznymi elementami zagospodarowania przestrzeni miejskiej) przy czym logika tych powiązań interpretowana jest w kategoriach stosowanych w teorii urbanistyki i regionalistyki. Spośród synergicznych sprzężeń między czynnikami rozwoju urbanistycznego na pierwszy plan wysuwa się logika funkcjonalnych i przestrzennych powiązań między układami transportowymi a pozostałymi elementami zagospodarowania przestrzennego. Natomiast hasło: logika procesu rozwojowego oznacza tutaj, przyjmowane na gruncie wymienionych dyscyplin interpretacje prawidłowości zmian w tych strukturach, które to wyjaśnienia mają - czy raczej powinny mieć - znaczenie przy podejmowaniu decyzji odpowiadających tym zmianom.

Załóżmy, że synergiczne właściwości rozwoju urbanistycznego to okoliczność pożądana, która powinna znaleźć swój wyraz w atrybutach planu urbanistycznym; w jego: formule (wynikającej z regulacji ustawowych i zasad sztuki urbanistycznej), ustaleniach planu (zapisanych w planie decyzjach) i strategiach wdrażania tych ustaleń.

Synergiczne atrybuty planu urbanistycznego wyrazić można w formie następującego zapisu:

$$
S_{u p}=\left\{a_{p f}, a_{p s}, a_{i s}\right\},
$$


gdzie: $S_{u p}$ - oznacza synergie generowane przez plan urbanistyczny - w skrócie: synergię planu urbanistycznego (synergy of urban plan); $a_{p f}$ - oznacza atrybuty formuły planu (attributes of planning formula) - np.: plan zagospodarowania przestrzennego; plan strategiczny; plan-zapis polityk; plan zintegrowany; plan kompleksowy; plan otwarty itp.); $a_{p s}-$ oznacza atrybuty ustaleń planu (attributes of planning statements) - np.: założenia planu, jego decyzje i warstwa informacyjna planu służąca jako przesłanki jego założeń i decyzji odgrywające rolę w pobudzaniu zjawisk synergii rozwoju urbanistycznego; $a_{i s}$ - oznacza atrybuty strategii realizacji planu (attributes of implementation strategy) - np.: wdrażania projektów, kluczowych dla realizacji planu (odpowiadających strategicznym priorytetom miasta) a zarazem ustalenia decyzyjne planu mogące pobudzać synergiczne relacje między tymi projektami.

Jeśli przyjmiemy, że atrybuty planu powinny być dostrojone do uniwersalnych praw rozwoju urbanistycznego, to powinniśmy uznać, że atrybuty planu powinny odpowiadać charakterystycznym cechom zjawisk określanych wcześniej jako „synergia rozwoju”. Zdanie to można zapisać używając formuły:

$$
S_{u p}=\left\{a_{p f}, a_{p s}, a_{i s}\right\} \leftrightarrow S_{u d}=\{L u f, L u d p\}
$$

Oznacza to, że synergię planu urbanistycznego można definiować jako jego zdolność do generowania synergicznych efektów rozwoju. Ta z kolei, zależy, w znacznej mierze, od charakterystyki planu; ujmując rzecz ściślej: synergia rozwoju urbanistycznego zależy od tego, czy formuła, ustalenia i sposoby wdrażania planu odpowiadają trafnemu odczytaniu cech rozwoju urbanistycznego. Natomiast synergiczne cechy rozwoju można utożsamiać $\mathrm{z}$,naturalną” logiką formy i logiką zmian noszącą znamiona uniwersalnych procesów rozwojowych zinterpretowanych odpowiednio do danej sytuacji planistycznej.

Historia urbanistyki wskazuje, że spośród szerokiej gamy czynników generujących synergię urbanistyczną, znaczenie szczególne mają takie oddziaływania między projektami, które prowadzą do wykrystalizowania nowej konstrukcji urbanistycznej. Konstrukcje tę tworzą węzły - nazwane tu węzłami miejskości - oraz powiązania między nimi. Pojęcie: „węzly miejskości” zdefiniować można [3,12,15] jako miejsca, które ze względu na dostępność, walory zagospodarowania przestrzennego, i inne wartości wysoko cenione, mają kluczowe znaczenie dla współczesnych form życia miejskiego. Dla wyjaśniania istoty tego pojęcia - i roli jaką może ono odegrać w teoretycznych interpretacjach konstrukcyjnej logiki struktur metropolitalnych - szczególne znaczenie ma związek tych miejsc węzłowych z prawem koncentracji. W teoriach urbanistyki i regionalistyki / gospodarki przestrzennej prawo to jest często uznawane jako naczelna zasada leżąca u podstaw większości procesów osadniczych $[1,2]$. Węzły miejskości to również miejsca, którym - wg. geografii ekonomicznej - odpowiadają punkty szczytowe na wykresach ilustrujących profile wartości przestrzeni metropolitalnej (peaks of property value). Zakres znaczeniowy pojęcia „węzły miejskości” można - w uproszczeniu - zilustrować schematem (Rys. 1), wg którego jest to część wspólna trzech zbiorów obejmujących:

- miejsca ogniskujące aktywności miejskie;

- węzły sieci urbanistycznej/metropolitalnej (węzły „konstrukcyjne”);

- projekty miejskie/metropolitalne zlokalizowane w miejscach węzłowych.

W proponowanym tu modelu planistycznym przyjmuje się, że spośród atrybutów ustaleń planu mających znaczenie w pobudzaniu synergii rozwoju szczególną rolę odgrywają synergiczne właściwości konstrukcji urbanistycznej: „potencjał synergiczny” węzłów mobilności i elementy planu tworzące strukturalne powiązania między tymi węzłami. Problem synergicznych wartości konstrukcji urbanistycznej stanowi teoretyczną podstawę autorskiej koncepcji modelu rozwoju Krakowa, jego obszaru metropolitalnego. Zakłada się, 
że ten kierunek myślenia może znaleźć zastosowanie także w pracach nad modelem rozwoju regionu metropolitalnego Górnego Śląska i Małopolski. Inspiracją dla tych poszukiwań mogą być niemal 70-cio letnie doświadczenia skandynawskie w planowaniu regionu metropolitalnego Kopenhagi oraz liczne studia poświęcone zarządzaniu rozwojem przestrzennym regionu Kopenhaga - Malmö. Relacje: synergia planu a konstrukcja urbanistyczna mogą być analizowane w kopenhaskich planach urbanistycznych stanowiących przykład konsekwentnego wdrażanie modelu zarysowanego w słynnym „Planie palczastym” Kopenhagi („Finger Plan”) pochodzącym jeszcze z 1947r. Można obronić tezę, że synergiczny potencjał planu urbanistycznego Kopenhagi wyraża się, w znacznej mierze, konstrukcyjną logiką, klarownością i trwałością zasad zapisanych w modelu rozwoju zapisanym w „Planie palczastym” tkwiącym u podstaw całej serii kolejnych planów sterujących rozwojem miasta i jego regionu.

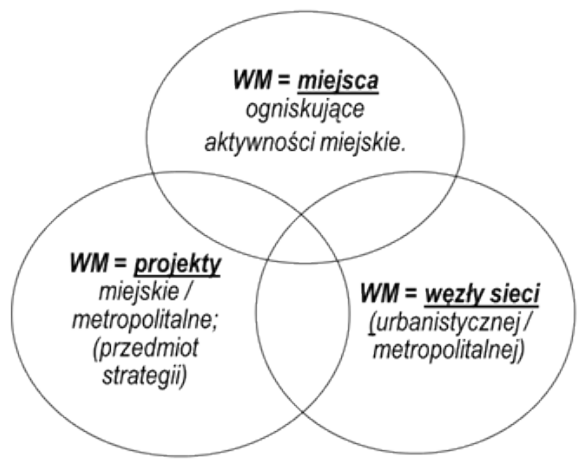

Rys. 1. Węzły miejskości - interpretacja zakresu pojęcia. Oprac. autor.

Analizy ustaleń tych planów [31,32,33,34,35] wskazują, że nowa konstrukcja urbanistyczna metropolii nie tylko nawiązuje do filozofii „Planu palczastego”, ale także - dzięki konsekwentnym wdrażaniu tego modelu - udało się wygenerować relacje synergiczne, a nawet impulsy zmian emergentnych $\mathrm{w}$ tym modelu dzięki inwestycjom infrastrukturalnym integrującym Kopenhagę i Malmö (Rys. 2a, Rys. 2b, Rys.3).

a)

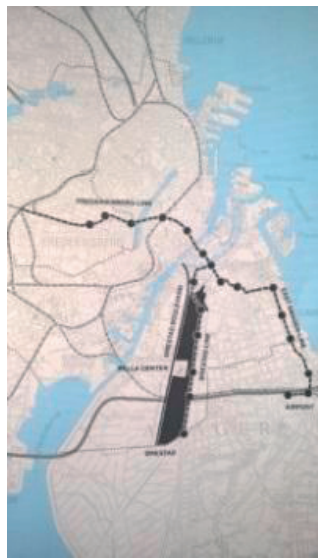

b)

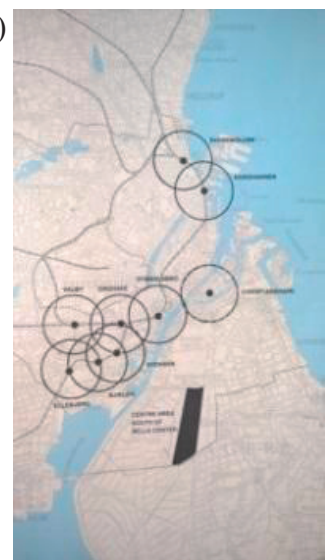

Rys. 2a,b. Wątki tematyczne Planu Municypalnego Kopenhagi z 1993 r. wskazujące na rolę konstrukcji urbanistycznej w synergii planów urbanistycznych w skali miejskiej, metropolitalnej i regionalnej. Źródło: [31] 


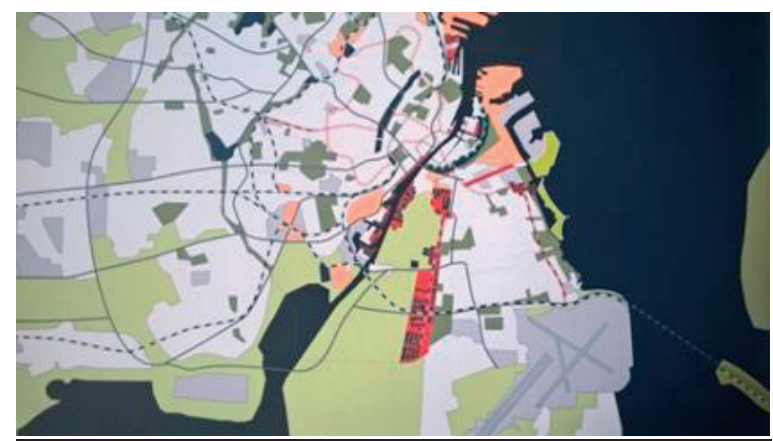

Rys. 3. Schemat planu rozwoju Kopenhagi. Źródło: [33,35]

Podejmując prace, których celem byłoby zbudowanie planistycznego modelu struktury funkcjonalno-przestrzennej Krakowa i Krakowskiego Obszaru Metropolitalnego należałoby określić elementy głównej konstrukcji urbanistycznych w obu tych układach oraz ustalić przesłanki/zasady przekształcania konstrukcji urbanistycznej miasta w konstrukcję metropolitalną. Dla obu tych zadań, kluczowe znaczenie będą miały odpowiedzi na następujące pytania:

- Jaką rolę w tej zmianie o charakterze modelowej odegrają zmiany w konstrukcji urbanistycznej śródmieścia Krakowa?

- Jak można zinterpretować charakterystyczne cechy geometrii tej konstrukcji?

- Które z węzłów mobilności odgrywają / odegrają rolę węzłów miejskości i jakie są warunki tego rodzaju transformacji?

Szkicowy rezultat pierwszych prób znalezienia odpowiedzi na te pytania ilustruje Rys. 5. Podobnie jak w przypadku Kopenhagi zdefiniowano główne węzły mobilności, zarówno te położone w skali śródmieścia, jak i główne węzły usytuowane w obszarach do niego przylegających. W odróżnieniu od geometrycznych cech kopenhaskiego modelu rozwoju miejskiej struktury przestrzennej, charakterystyczne cechy śródmiejskiej konstrukcji urbanistycznej Krakowa można wyrazić w postaci następujących stwierdzeń:

- Główne węzły mobilności sytuują się na obwodnicy wyznaczającej granicę między centrum a pozostałymi strefami śródmieścia.

- Stosunkowo słabo krystalizują się węzły mobilności na kierunkach promienistych, co pewną osobliwością, zważywszy, że tradycyjnie układ Krakowa był promienisto-obwodnicowy.

- Pomimo wielokrotnie składanych deklaracji planistycznych, przystanki kolejowe z wyjątkiem Krakowskiego Centrum Komunikacyjnego nie spełniają funkcji węzłów mobilności.

Wróćmy jednak do głównego pytania postawionego w tym artykule, a mianowicie: Jakie oddzialywania urbanistyczne wywotuja efekt synergii? Jest to pytanie o związek między ideami synergii i ładu urbanistycznego a koncepcjami modelowymi oraz instrumentami strategii i polityk rozwoju urbanistycznego. Autor stawia hipotezę, że odpowiedzią na pytanie o synergiczny model sterowania rozwojem urbanistycznym może być model wyrażony tu akronimem „SAS” (strategie - aktorzy - struktury). W kontekście takiego modelu (Rys. 4), postawiony na wstępie problem pytanie można teraz wyrazić w formie pytania: Jakie relacje typu: „SAS” będą sprzyjać konfigurowaniu projektów miejskich? Rozwijając naszą hipotezą, przyjmuje się, że: oddziaływania synergiczne powstają dzięki odpowiednim relacjom między strategiami, planami i ich podmiotami a realnymi zmianami w strukturach miejskich (fizycznych, społecznych, ekonomicznych, kulturowych). 
W wytwarzaniu relacji synergicznych szczególne znaczenie ma budowanie powiązań między projektami urbanistycznymi. W planowaniu rozwoju terytorialnego integrującym ustalenia właściwe planowaniu przestrzennym z treściami charakterystycznymi dla planowania strategicznego, kwestią zasadniczą jest konieczność przyjęcia klarownych zasad kojarzących relacje między kluczowymi elementami przestrzennej struktury miasta a celami i zadaniami przyjętymi w strategii rozwoju. Oznacza to, że w technice zapisu ustaleń odnoszących się do konstrukcji urbanistycznej powinny znaleźć się sformułowania dotyczące zarówno „konstrukcyjnych” elementów zagospodarowani przestrzennego jak i treści właściwe dla planowania społeczno-gospodarczego.

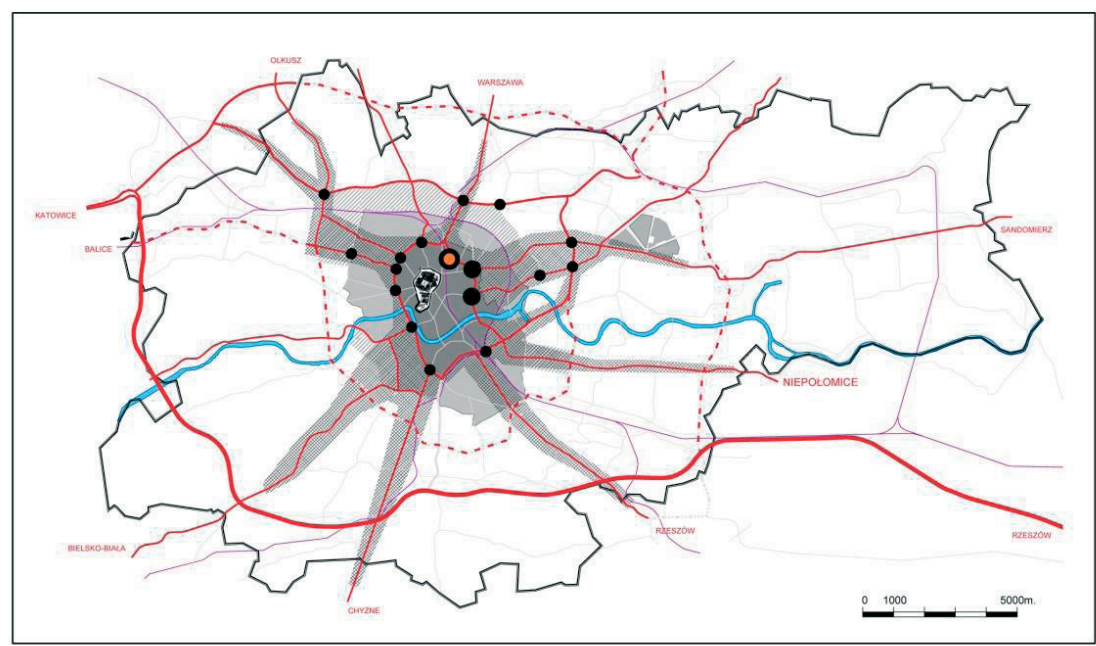

\section{LEGENDA:}
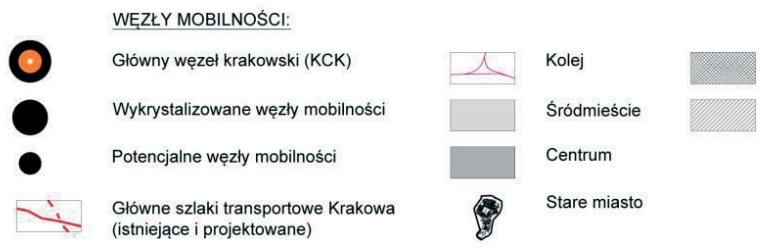

Obszary oddziaływania śródmiejskich węzłów mobilności

Potencjalny zakres nowej delimitacji strefy śródmiejskiej

Stare miasto

Rys. 5. Schemat konstrukcji urbanistycznej Miasta Krakowa jako punkt wyjścia do prac nad modelowaniem przestrzennej struktury Krakowskiego Obszaru Metropolitalnego. Oprac. Mirosław Maniecki, 2016

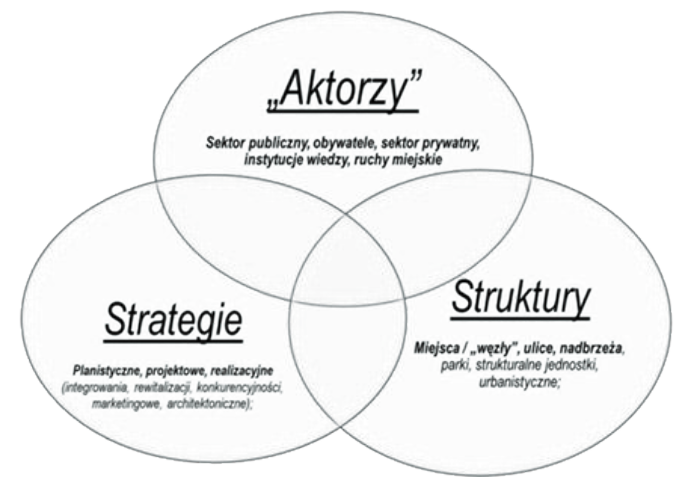

Rys. 4. Ideogram modelu SAS. Oprac. autor 


\section{Konfigurowanie projektów i śródmiejskiej konstrukcji urbanistycznej: wstęp do analizy}

W myśl przyjętych wcześniej założeń, dostrojenie strategii integrowania projektów miejskich do charakterystycznych cech konstrukcji urbanistycznej danego obszaru to istotny warunek znaczącego wzrostu prawdopodobieństwa pojawienia się synergicznych relacji między tymi projektami. Innymi słowy, ten rodzaj koncepcji integrowania projektów urbanistycznych określić można jako tworzenie planistycznych warunków budowania konstrukcji urbanistycznej o geometrii sprzyjającej synergicznemu konfigurowaniu projektów, przy założeniu, że istnieje logiczna spójność między: strategiami prowadzenia tych projektów a strategią rozwoju miasta, której wyrazem jest ta konstrukcja. Czas jednak, aby te ogólne rozważania zilustrować odpowiednimi przykładami analiz. Ich przedmiotem jest logika powiązań funkcjonalno-przestrzennych między „konstrukcją urbanistyczna” śródmieścia a projektami miejskimi o kluczowym znaczeniu dla nowego modelu struktury funkcjonalno-przestrzennej śródmieść Krakowa i Poznania. Intencją autora było wydobycie podobieństw i różnic między sytuacjami planistycznymi obu tych miast, przyjmując, że porównania strukturalnych i planistycznych uwarunkowań rozwoju obszarów śródmiejskich prowadzić należy w ramach podobnych kategorii miast.

W przypadku Krakowa, analiza potencjalnych efektów synergii miedzy konstrukcją urbanistyczną śródmieścia i projektami miejskimi, które mają znaczenie metropolitalne i zlokalizowane są w węzłach tej konstrukcji, uwzględniać powinna, co najmniej, cztery typy sytuacji planistycznych. Odpowiadają one typom głównych układów funkcjonalnoprzestrzennych składających się na konstrukcję śródmieścia. Są to:

- sieć śródmiejskich przestrzeni publicznych zdefiniowana przez konfigurację placów miejskich powiązanych siecią ulic o znaczeniu śródmiejskim (Rys. 6);

- powiązania między śródmiejskimi węzłami mobilności i innymi miejscami, które można uznać jako węzły miejskości (Rys. 7);

- układ przystanków szybkiej kolei aglomeracyjnej (SKA) stanowiących potencjalne miejsca synergii krystalizującej nowe węzły miejskości (Rys. 8);

- układ przestrzenny Bulwarów Rzeki Wisły, w którym role szczególną odgrywać będą mosty piesze i rowerowe (Rys. 9).
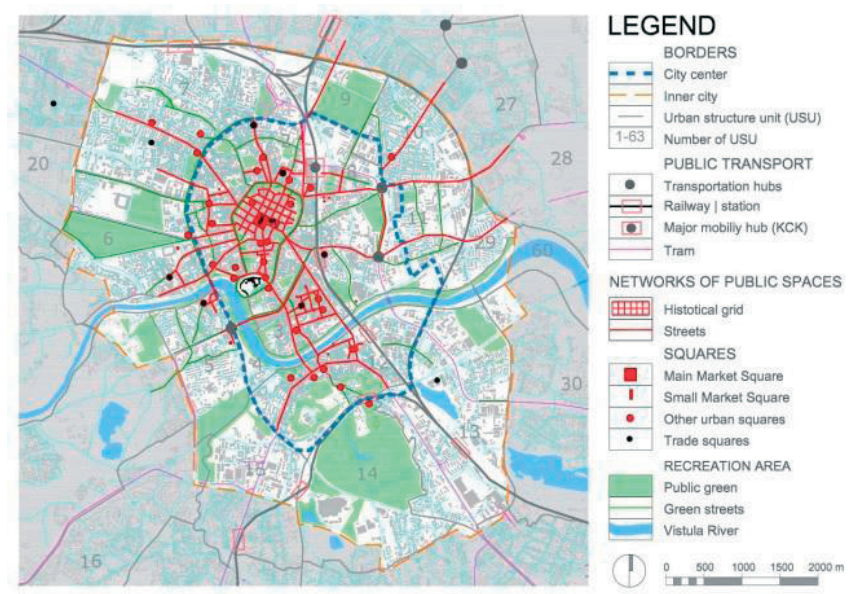

Rys. 6. Sieć śródmiejskich przestrzeni publicznych Krakowa zdefiniowana przez konfigurację placów miejskich powiązanych siecią ulic śródmiejskich. Oprac.: Anna Macek, 2016 

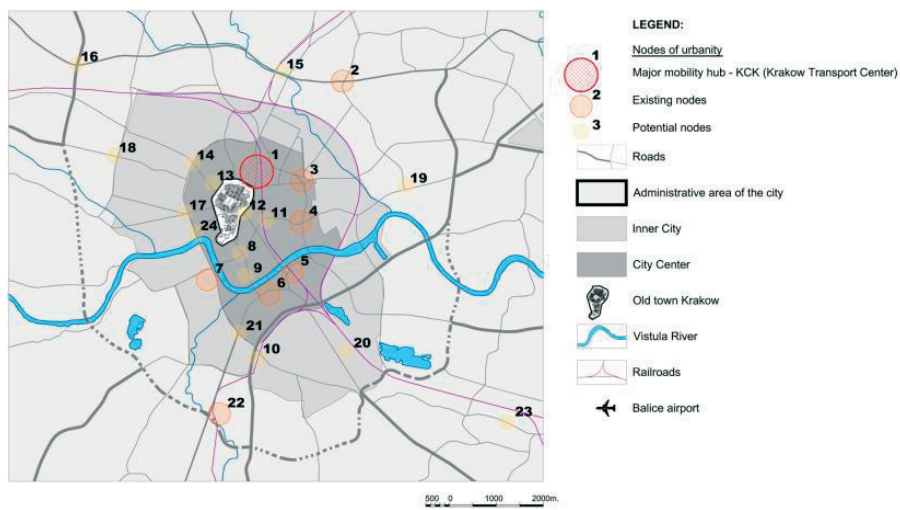

Rys. 7. Śródmiejskie węzły miejskości Krakowa a projekty miejskie i metropolitalne. Oprac.: Mirosław Maniecki, 2016. Ważniejsze miejsca węzłowe: 1. KCK, 2. Węzeł Polsadu, 3. Węzeł Mogilski, 4. Węzeł Grzegórzecki, 5. Plac Boh. Getta, 7. ICE, 9. Plac Wolnica, 14. Plac Inwalidów, 17. Plac przed Muzeum Narodowym, 18. Centrum biurowe przy Al. Armii krajowej, 19. Tauron Arena, 22. Sanktuarium Bożego Miłosierdzia

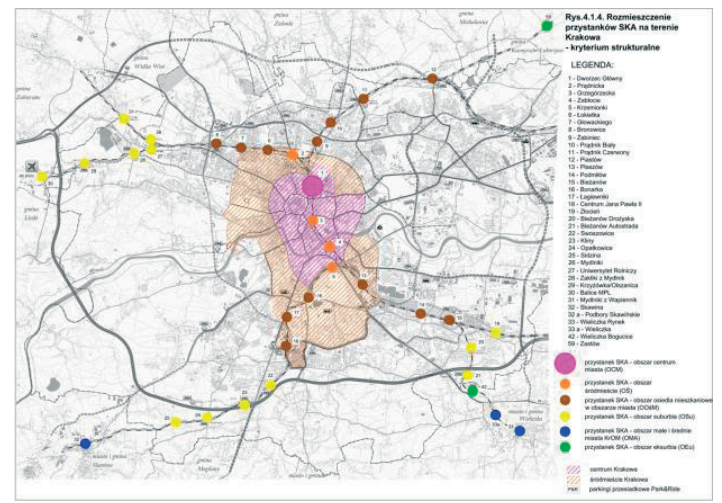

Rys. 8. Schemat rozmieszczenia przystanków szybkiej kolei aglomeracyjnej (SKA) w Krakowie stanowiących potencjalne miejsca synergii krystalizującej nowe węzły miejskości. Wg. oprac.: Aleksandry Faron, 2014

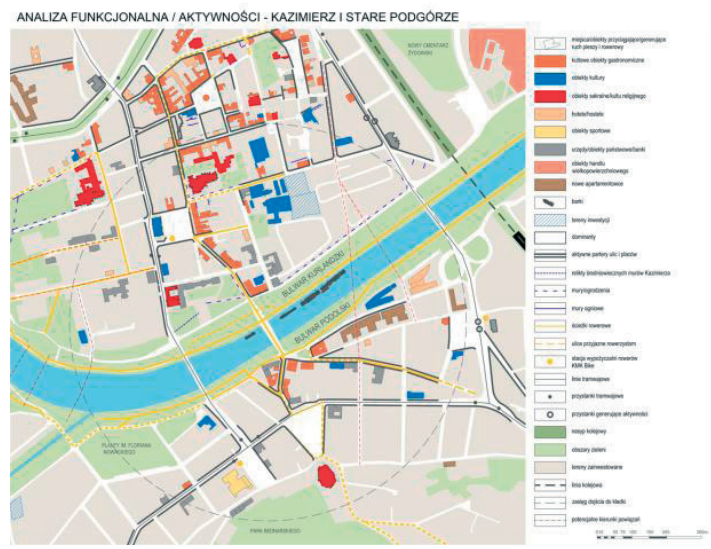

Rys. 9. Synergiczne oddziaływanie mostu pieszego i rowerowego: przypadek kładki O. Bernatka łączącej krakowski Kazimierz i Stare Podgórze. Oprac.: Aneta Sarga, 2016 
W analizach tych, szczególną rolę odgrywa konfiguracja węzłów miejskości powiązanych pod względem funkcjonalno-przestrzennym z „kwartałem dworcowym” - czyli obszarem wyznaczonym wokół głównego węzła mobilności, który tworzy tzw. Krakowskie Centrum Komunikacyjne. W planach urbanistycznych Krakowa - począwszy od lat 1960. do pierwszej dekady naszego stulecia - obszar ten planowany był jako tzw. nowe centrum. (Rys. 10).

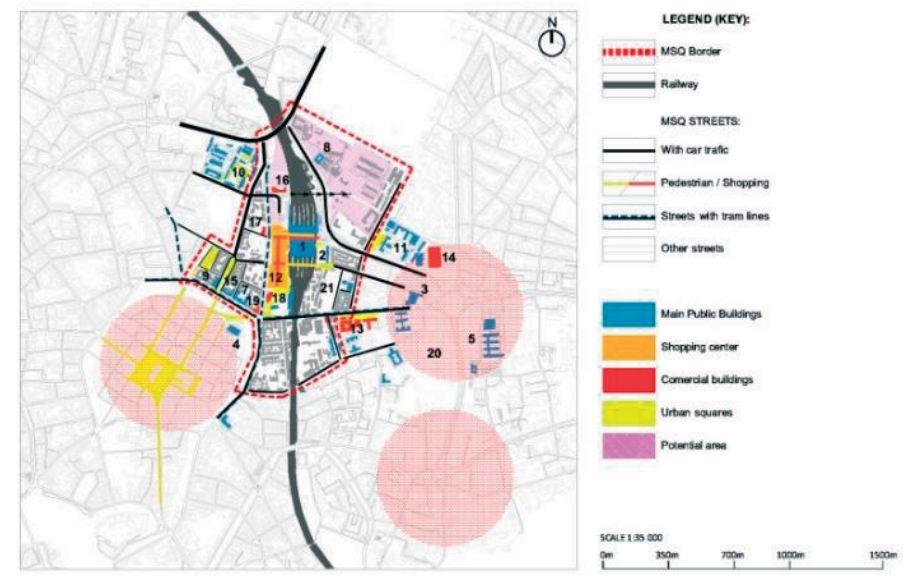

Rys. 10. „Kwartał dworcowy” na tle wybranych węzłów miejskości śródmieścia Krakowa. Oprac. Szymon Wójtowicz, 2016. (z nieopublikowanego opracowania: S. Wójtowicz, „Śródmiejskie dzielnice dworcowe - analiza powiązań między konstrukcją urbanistyczną a węzłami mobilności i projektami urbanistycznymi”). Ważniejsze miejsca: 1. Dworzec główny, 2. Główny dworzec autobusowy, 4. Teatr Słowackiego, 5. Zespół Sądów, 6. Oddział Urzędu Miasta Krakowa, 7. Urząd Wojewódzki i Urząd Marszałkowski, 8. Muzeum Armii Krajowej, 9. Akademia Sztuk Pięknych, 10. Politechnika Krakowska, 11. Uniwersytet Ekonomiczny w Krakowie, 12. Galeria Krakowska, 13. Lubicz Business Center. 14. Centrum biurowe: Unity Tower, 20. Ogród Botaniczny

Porównując wyniki przedstawionych wyżej wstępnych analiz ze wstępnymi rezultatami badań dotyczących analogicznych obszarów w Poznaniu (Rys. 11 i Rys. 12) dostrzega się zarówno pewne podobieństwa jak i dość istotne różnice. Czynnikami różnicującymi są tu - między innymi - nieporównywalna pozycja krakowskiego centrum historycznego a także różnice $\mathrm{w}$ prowadzeniu strategicznego projektu przebudowy otoczenia głównego dworca kolejowego. Jak dotąd, w przypadku Poznania można mówić o serii niepowodzeń, których najlepszą egzemplifikacją jest niepochlebna opinia jaką dość powszechnie panuje na temat architektoniczno-urbanistycznych rozwiązań dworca kolejowego Poznań Główny i jego bezpośredniego otoczenia. Dotyczy to zwłaszcza niefortunnych relacji funkcjonalnoprzestrzennych między budynkiem dworca i przylegającą do niego galerią handlową oraz braku czytelnej sieci przestrzeni publicznej. Natomiast pewne nadzieje można wiązać $\mathrm{z}$ rezultatami konkursu na tzw. Wolne Tory. Koncepcje budowania sieci przestrzeni publicznej w obszarze Wolnych Torów w Poznaniu prezentowane w pracach nagrodzonych i wyróżnionych w konkursie na zagospodarowanie przestrzenne tego obszaru, to przykłady myślenia kategoriami synergii planu w relacjach: plan - projekt (Rys. 13). 


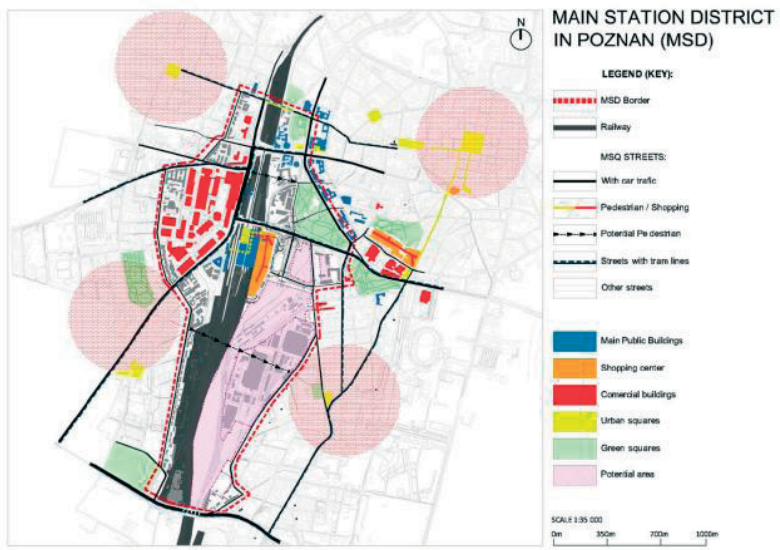

Rys. 11. „Kwartał dworcowy” na tle wybranych węzłów miejskości śródmieścia Poznania. Oprac. Szymon Wójtowicz, 2016

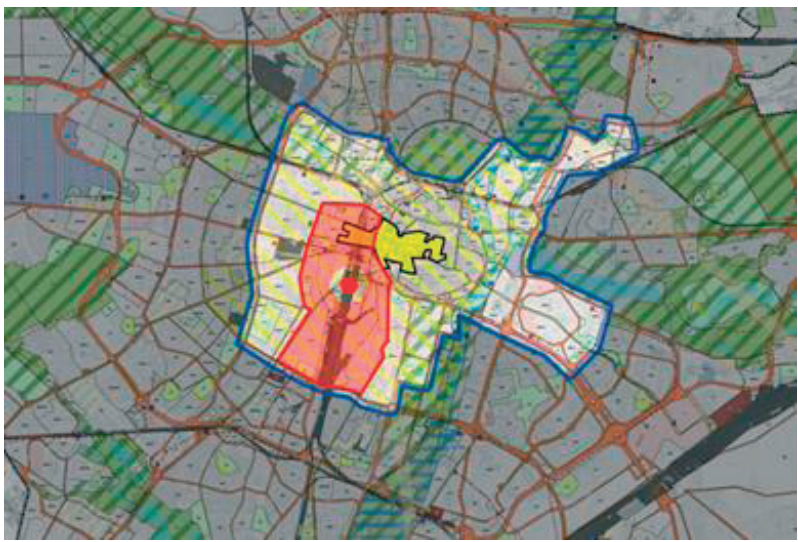

Rys. 12. Zasięg „dzielnicy dworcowej” w Poznaniu. Oprac.: Szymon Wójtowicz, 2016

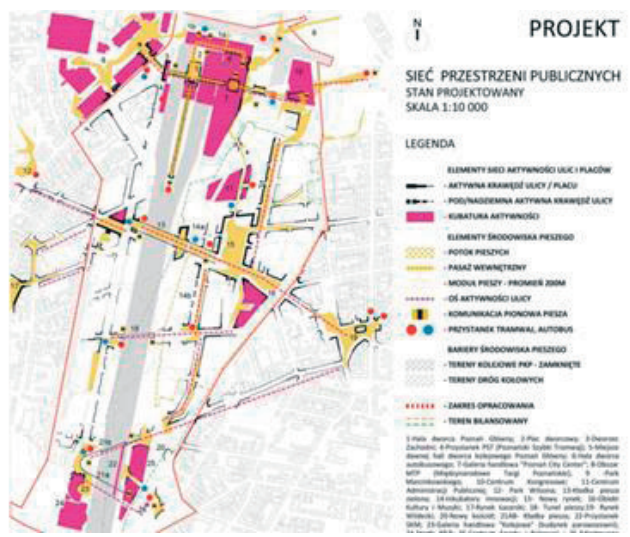

Rys. 13. Koncepcja sieci przestrzeni publicznej w obszarze Wolnych Torów w Poznaniu. - fragment pracy konkursowej zespołu autorskiego pracowni: Wojtyś -Wójtowicz, Poznań, 2015;[38], Oprac.: Szymon Wójtowicz, 2015 


\section{Podsumowanie}

W rozważaniach nad synergicznymi atrybutami planu urbanistycznego wyróżniono warunki sprzyjające powstaniu takich efektów. Pierwszą istotną okolicznością warunkującą uzyskanie efektu synergicznego jest wypracowanie rozwiązań instytucjonalnych umożliwiających integrację strategii urbanistycznych w ramach różnych rodzajów planowania. Drugi warunek synergii urbanistycznej dotyczy samej formuły planu i oznacza konieczność zapewnienia odpowiednich powiązań między projektami strategicznymi a „konstrukcją urbanistyczną", czyli układem głównych elementów fizycznych krystalizujących strukturę przestrzenną planowanego terytorium. Przykłady dobrych praktyk potwierdzają rolę konstrukcji urbanistycznej jako czynnika synergii urbanistycznej. Tym samym potwierdzają znaczenie projektowania urbanistycznego w planowaniu miast. Projektowanie urbanistyczne staje się znów kluczowym narzędziem definiowania konstrukcji urbanistycznej. Dotyczy to zwłaszcza potencjalnych efektów synergii planu, jakie mogą powstać dzięki ustaleniom planistycznym dotyczącym budowania sieci przestrzeni publicznych.

Głównym przesłaniem, jakie wyprowadzić można z przeprowadzanych tu rozważań jest teza o konieczności prowadzenia badań nad zmianami w strukturze przestrzennej śródmieść metropolitalnych pod kątem zdolności konstrukcji urbanistycznej śródmieścia do indukowanie synergii między projektami miejskimi. Mowa tu o szansach synergicznej akumulacji potencjału ożywiającego przestrzeń śródmiejską. Uzyskanie takiego efektu prowadzić powinno do zwiększenia atrakcyjność śródmieścia dla mieszkańców i przedsiębiorców. Tym samym wzmacnia się - relatywnie - znaczenie oddziałania sił dośrodkowych (do centrum) w stosunku do oddziaływań odśrodkowych (od centrum ku peryferiom). To z kolei, może być traktowane jako okoliczność przeciwdziałająca natężeniu suburbanizacji.

\section{Literatura}

1. Zipser T. Aktualna doktryna urbanistyczna wśród ślepych uliczek. Urbanistyka w działaniu. Teoria i praktyka, red.: Ossowicz T., Zipser T., Urbanista, Warszawa, 2006, s. 114-121.

2. Zipser T. Powiazania transportowe jako generatory struktury przestrzennej systemu osadniczego. Czasopismo Techniczne 3 (2010) 21-30.

3. Zuziak Z.K. The Notion of Order and the Spatial Logic of a New Polis: Three Approaches to the Problem of Rationality in the Contemporary Philosophy of Urbanism, 11 CTV, Back to the sense of the City, Barcelona, Kraków, 2016.

4. Rudnicki A. Zrównoważona mobilność a rozwój przestrzenny miasta. Czasopismo Techniczne 3(1-A) (2010) 57-74.

5. Szarata A. Zrównoważona mobilność a rozwój przestrzenny miasta. Czasopismo Techniczne 3(1-A) (2010) 249-261

6. Zuziak Z.K. Forma metropolitalna i zrównoważona mobilność. Czasopismo Techniczne 3 (2010) 75-91.

7. Zuziak Z.K. Urbanism and Cultural Heritage Strategies. Actors and Structures in the Labyrinth of Urbanity. Journal of Heritage Conservation, 43 / 2015, 19-32.

8. Aysar A. Quantum Urbanism, Urban design in The Post-Cartesian Paradigm. Tigran Haas (Ed), New Urbanism and Beyond. Designing Cities for the Future, Rizzoli International Publications, New York, 2008.

9. Meijers E. Synergy in Polycentric Urban Regions. Complementarity, organising capacity and critical mass. Cities and networks, from central place to a network model., TU Delft, 2007.

10. Boelens L. The Urban Connection. An actor - relational approach to urban planning, 010 Publishers, Rotterdam, 2009.

11. Zuziak Z.K. O tożsamości urbanistyki. Politechnika Krakowska im. Tadeusza Kościuszki, 2008 . 
12. Zuziak Z.K., Nowe struktury w przestrzeni metropolitalnej. Pytania i problemy planistyczne. Czasopismo Techniczne 5-A (2008) 4-18.

13. Zuziak Z.K. Strategiczne węzty w przestrzeni przepływów. Czasopismo Techniczne 10 (2011) 41-47.

14. Wrana J., Rola i znaczenie architektury w procesie scalania struktury przestrzennej miasta na przyktadzie Lublina, Monografia, Politechnika Lubelska, Lublin, 2014

15. Zuziak Z.K. Zmiany strukturalne w miastach polskich na początku XXI. Między sztuka budowania miast a polityka przestrzenna. Halicka A.(red), Budownictwo na obszarach zurbanizowanych. Nauka, praktyka, perspektywy, Lublin. Politechnika Lubelska; s.165-176, 2014.

16. Stangel M. Rozwój strefy okołolotniskowej a port lotniczy. Efekt synergii. Przegląd Komunikacyjny 7 (2013) 18-25.

17. Stangel M. Kształtowanie współczesnych obszarów miejskich w kontekście zrównoważonego rozwoju. Wydawnictwo Politechniki Śląskiej, Gliwice, 2013.

18. Calthrope P. The Urban Network. Haas Tigran, (ed.), New Urbanism and Beyond. Designing Cities for the Future, Rizzoli, New York, 2008.

19. Hillier B. The New Science of Space and the Art of Place. Towards a Space-led Paradigm for Researching and Designing the City. New Urbanism and Beyond. Designing Cities for the Future, Haas Tigran, (ed.), Rizzoli, New York, 2008.

20. Hillier B. The City as a Socio-Technical System: a spatial reformulation in the light of the levels problem and the parallel problem. Proc., the Conference on Spatial Information Theory, September 2009.

21. Salat S. Resilient and efficient synergy communities. A morphological, structural and synergetic approach to energy efficiency,

http://www.ambafrance-cn.org/IMG/pdf/icgeeb_beijing_2012.pdf . (2016, 07.03).

22. Vanegas C.A., Daniel G., Aliaga D.G., (i inni). Visualization of Simulated Urban Spaces:

Inferring Parameterized Generation of Streets, Parcels, and Aerial Imagery. IEEE Transac-

tions on Visualization and Computer Graphics, Tvcg-2008-07-0094.R1, https://www.cs.purdue.edu/cgvlab/papers/aliaga/tvcg09-urban.pdf (2016. 07.03).

23. Minner J. Revealing Synergies, Tensions, and Silences Between Preservation and Planning. Journal of the American Planning Association 82(2) (2016) 72-87, http://dx.doi.org/10.1080/01944363.2016.1147976

24. Shladover S.E. Bus Rapid Transit and Automation: Opportunities for Synergy. http://www.trb.org/conferences/VHA-BRT/Bus_Rapid_Transit_and_Automation-Opportunities_for_Synergy.pdf

25. Böhm A. O budowie i synergii wnętrz urbanistycznych. Monografia, Politechnika Krakowska, Kraków, 1981.

26. Wejchert K. Elementy kompozycji urbanistycznej. Warszawa, 1974.

27. Busquets J. Urban compositions: City Design in the 21st Century. Graafland Arie, Leslie Jaye Kavanaugh (eds.), Crossover. Architecture, Urbanism, Technology, 010 Publishers, Rotterdam, 2006. p. 494-504.

28. Meyer H. Urban Compositions. Graafland Arie, Leslie Jaye Kavanaugh (eds.), Crossover. Architecture, Urbanism, Technology, 010 Publishers, Rotterdam, 2006. p. 487-491.

29. Burkhard R. Visualizing Desires not Cities. Thierstein Alain, Agnes Förster (Eds), The Image and the Region - Making Mega City Regions Visible, Lars Müller Publishers, Baden, Switzerland, 2008, s. 168-179.

30. Thierstein A., Förster A., (eds.) The Image and the Region-Making - Making Mega-City Regions Visible! Lars Müller Publishers, München, 2008.

31. Copenhagen Municipal Plan 1993. The Municipal Corporation of Copenhagen, The Lord Mayor's Department, Copenhagen, 1993.

32. Jensen P.B. Regional planning in Greater Copenhagen - history, current state and future prospects. Interplan No 11, May, 1992.

33. Meyer U.M. Copenhagen. Johan Jesse, Ute Margarete Meyer i inni (pod redakcją), Stadtmachen, eu. Urbanity and the Planning Culture in Europe, Karl Krämer Verlag, Stuttgart, 2008. 
34. Jessen J, Meyer U.M., Schneider J. (red.), Stadtmachen. Eu. Urbanity and the Planning Culture in Europe. Stuttgart. Karl Krämer Verlag, 2008.

35. Stadtmachen, Eu. Urbanity and the Planning Culture in Europe (ed. Jessen J, Meyer U. M., Schneider J.), Karl Krämer Verlag, Stuttgart, 2008.

36. Zuziak Z.K., A Homo Ludens and the Nodes of Urbanity. Places, Maps, Metaphors, Technical Transactions, Architecture 8-A(111) (2015) 239-119.

37. Zuziak Z.K., A House and a Territory. Ideas, Values, Strategies, Technical Transactions, Architecture, Issue 10-A (23), year 2014 (111), p. 111-119.

38. Konkurs - Wolne Tory, Arch, Nr 1 (2016/33) 40-52.

\title{
On the synergy of urban plan
}

\author{
Zbigniew Karol Zuziak \\ Chair of Spatial Planning and Environmental Protection, Faculty of Architecture, \\ Cracow University of Technology, e-mail: zzuziak@nsnet.pl
}

\begin{abstract}
In this paper the interpretation of synergic effects of planning decisions is discussed in the context of urban development strategies and respective attributes of urban plan. The author presents the concept of urban planning formula according to the model named as SAS (acronym from: strategies, actors, structures). This concept refers to urban strategies requiring new urban policy tools and even the reform of existing land use controls system. These changes should allow for better logical connections between spatial planning, strategic planning and urban design. Regarding potentials for inducing synergic effect of urban development as the assessment criterion of the plan, the author discusses the attributes of this plan which are appropriate to stimulate synergic functional links between the elements of land use arrangement, designed in a given planning document, and respective changes in socio-economic and cultural space. Two situations were identified as circumstances generating such effects. First type of such preconditions is described as the postulate to provide clear structural relations between strategic projects and "urbanistic construction" defined as the layout of main physical elements crystalizing spatial structure of the territory covered by the plan. Second significant type of preconditions for achieving synergic effects of the plan depends on the type of urban development strategies including the implementation strategy of key projects. Lessons learned from the cases of good practice in the area of operational urbanism indicate that mutually beneficial effects of interactions between key urban projects can be observed in case of implementation strategies where the respective rules of implementation are clearly defined with regard to urban construction of the planned land use layout. Significant role is also played here by the consistent implementation of the model defined in the long term vision for city development. Such a situation can be exemplified by the principles of urban development strategy defined for metropolitan Copenhagen in the concept known as the "Finger Plan".
\end{abstract}

Keywords: synergy, urban planning, urbanism, urban projects, urban construction, urban strategies. 